\title{
EDUCAÇÃO INFANTIL: O LUGAR DO APRENDER NO CAMPO
}

\author{
Mayara de Carvalho Soares-UFCG \\ Mayaracarvalhosoares12@gmail.com
}

PALAVRAS-CHAVE: Educação no campo, Educação Infantil, Formação de Professores.

\section{INTRODUÇÃO}

O referido texto trata da importância das estratégias de ensino na educação infantil, na escola do Campo. A pesquisa emerge da observação direta da autora, de que as vivências educacionais pelas crianças do campo na educação infantil é um terreno fértil para se pensar na superação do mecanicismo precoce da educação infantil. Iremos tratar essas questões pensando a "educação no campo", "educação infantill" e "formação de professores". Nossa pergunta de partida é a seguinte: quais são as estratégias de ensino trabalhadas na Educação Infantil em um município do sertão paraibano? Partimos do pressuposto que a adoção de práticas pedagógicas abertas centradas na criatividade e autonomia com diversidade da expressão da arte, como instrumento didático torna o ensino agradável e eficiente para as crianças do Campo. Portanto, pretendemos identificar as estratégias de ensino e seu impacto afetivo e cognitivo na aprendizagem de crianças da Educação Infantil que residem no campo. O estudo baseia-se na perspectiva fenomenológico-hermenêutica, considerando a intenção de interpretação e compreensão do fenômeno específico do ensino. Para o desenvolvimento da pesquisa utilizaremos a pesquisa de campo com uso de entrevista semiestruturada para a professora e de teste de desenho, aplicado aos educandos da educação infantil. Esperamos contribuir com as discussões sobre a formação de professores e seu olhar sobre a educação infantil no Campo.

Historicamente, a Educação do Campo criada em 2004, pelo Ministério da educação e cultura - MEC, na Secretaria de Educação Continuada, Alfabetização e Diversidade SECAD/MEC, por meio da Coordenação Geral de Educação do Campo - CGEC denotam sua recente inclusão na pauta de política educacional. Por igual, é apontada em pesquisas a carência de estudos sobre esse importante processo educacional nos cursos de formação de professores. 


\section{METODOLOGIA}

A pesquisa a ser desenvolvida será de abordagem qualitativa (CRESWELL, 2007, GÜNTHER, 2006, NOVIKOFF, 2010), considerando importante descrever a realidade sem intervir, nem mensurar quantitativamente os eventos.

A abordagem dimensional ancorada na proposta de desenvolvimento de pesquisa em Novikoff (2010) trata-se de uma proposta de ensino de pesquisa em que o tempo e o espaço irregular, fractal é impulsionador das atividades a serem realizadas, passando por cinco dimensões de pesquisa. São elas: dimensão epistemológica, dimensão teórica, dimensão técnica, dimensão morfológica e dimensão analítico-conclusiva.

A pesquisa será desenvolvida com alunos e professora se enquadra dentro da técnica de estudo de caso de uma turma da educação infantil, de uma escola municipal, localizada em um município do sertão paraibano.

A coleta de dados teóricos se dará por meio da TABDN que contem os elementos necessários para pensar o conhecimento científico.

Para a análise dos dados usaremos a análise de conteúdo conforme Bardin (2011). Trata-se, portanto, de uma técnica que não tem modelo pronto, mas que constrói-se através de uma vai-e-vem contínuo e tem que ser reinventada a cada momento.

Em síntese, os métodos utilizados percorrerão cinco etapas, após a sua aprovação no Comitê de Ética para Pesquisa com Seres Humanos (CEP). As etapas são: 1) Elaboração do estado do conhecimento por meio da TABDN; 2) Contrato de pesquisa via Termo de Consentimento Livre e Esclarecido -TCLE para os pais ou responsáveis (ANEXO 3); Contrato de pesquisa via Termo de Consentimento Livre e Esclarecido -TCLE para professora participante-colaboradora (ANEXO 4); 3) Aplicação do teste de desenho (ANEXO 5); 4) entrevista semiestruturada (ANEXO 6); 5) elaboração do relatório em forma de monografia.

\section{DESCRIÇÕES, RESULTADOS, INTERPRETAÇÕES}

Foram estudados até o presente momento dez artigos que tratam sobre o tema, sinteticamente a educação no campo é pouco discutida e nos cursos de formação de professores fica no campo teórico sem a devida prática 


\section{CONSIDERAÇÕES FINAIS}

Através deste estudo buscamos perceber a educação infantil no campo como fundamental para a formação do sujeito, tendo em vista a educação como meio de mudança da realidade, observando as dificuldades enfrentadas por educadores e educandos, e contribuindo para uma revisão crítica acerca da educação infantil no campo, prezando sempre pela qualidade da educação e observando o educando como principal interessado em uma prática prazerosa, dinâmica e que forme-o como sujeito de direitos, preparando-o para os anos seguintes da educação e para suas vivências cotidianas.

Desta forma, a pesquisa nos aproxima da realidade do contexto em estudo, nos tornando capazes de vivenciarmos a prática através do embasamento teórico e do contato com a realidade.

\section{REFERÊNCIAS}

CRESWELL, J. W. Projeto de Pesquisa: métodos qualitativo, quantitativo e misto. Porto Alegre: Artmed, 2007.

GÜNTHER, Hartmut. Pesquisa Qualitativa Versus Pesquisa Quantitativa: Esta É a Questão? In Psicologia: Teoria e Pesquisa. Mai-Ago 2006, Vol. 22 n. 2, pp. 201-210.

KISHIMOTO, Tikuzo Morchida. Política de formação profissional para a educação infantil: Pedagogia e Normal Superior. Educ. Soc. vol.20 n.68 Campinas Dec. 1999.

KREPPNER, K. (2000). The child and the family: Interdependence in developmental pathways. Psicologia: Teoria e Pesquisa, 16(1), 11-22.

MARTINS, José Fernandes. Educação do Campo: processo de ocupação social e escolar. Congr. Intern. Pedagogia Social Mar. São Paulo. 2009.

NOVIKOFF, C. Dimensões Novikoff: um constructo para o ensino-aprendizado da pesquisa. In ROCHA, J. G. e NOVIKOFF, C. (orgs.).Desafios da práxis educacional à promoção humana na contemporaneidade. Rio de Janeiro: Espalhafato Comunicação, p. 211-242, 2010.

OLIVEIRA, Maria Izete de. Educação infantil: legislação e prática pedagógica. Psicol. educ. n.27 São Paulo dez. 2008. 